\title{
Incorporation of Thymine into Prototrophic and Thymine- dependent Mutants of Bacillus anthracis
}

\author{
By G. IVÁNOVICS, A. DOBOZY AND L. PÁL \\ Institute of Microbiology, Medical University, Szeged, Hungary
}

(Accepted for publication Io September 1969)

\begin{abstract}
SUMMARY
Mutants of Bacillus anthracis which were prototrophic in a defined medium below $32^{\circ}$ required either thymidine (mutant thy) or low concentration of thymine (mutant thytlr) for growth at $37^{\circ}$. No thymidylate synthetase was produced by these mutants at $37^{\circ}$. Normal enzyme activity was found in bacteria grown at $25^{\circ}$. Absence of thymidylate synthetase activity in bacteria grown at $37^{\circ}$ could not be accounted for either by a heat-sensitive enzyme protein or by an inhibitor of this enzyme activity.

The incorporation of thymine by prototrophic bacteria of Bacillus anthracis was negligible at either temperature. Mutant thy tlr and its prototrophic revertant both readily took up thymine at $37^{\circ}$ but not at $25^{\circ}$. Thymine uptake by both prototrophic and thy bacteria was markedly enhanced by the presence of any of the deoxyribonucleosides except thymidine. Moreover, thymidine antagonized thymine uptake. No thymidine phosphorylase activity was detected in $B$. anthracis, but phosphorolytic decomposition of deoxyuridine was found and that of deoxyadenosine seemed likely. The phosphorolytic reaction of deoxyuridine resulted in an accumulation of deoxyribose by thytlr bacteria, whilst both wild-type and thy bacteria catabolized this sugar. The secondary mutation in thy bacteria presumably resulted in a defect in synthesis of 1,5 -phosphodeoxyribo mutase or deoxyribose 5-phosphate aldolase (E.C. 4.I.2.4). Although no thymidine phosphorylase was detected in B. anthracis, resting suspensions of this bacterium transferred the deoxyribosyl moiety from thymidine to thymine. This indicates the presence of the enzyme nucleoside purine (pyrimidine) deoxyribosyl transferase in B. anthracis. This particular enzyme may also be involved in the increased thymine uptake in the presence of different deoxyribonucleosides.
\end{abstract}

\section{INTRODUCTION}

The isolation of mutants from Bacillus anthracis unable to synthesize thymidine nucleotide has been reported (Ivánovics, 1964). These mutants required thymine for growth only when they were cultivated in a defined medium for $B$. anthracis at temperatures above $32^{\circ}$. To approach the uniform nomenclature in bacterial genetics recommended by Demerec et al. (I966), mutant $\mathrm{VC}^{-} \mathrm{TdR}^{-}$isolated from prototrophic bacteria will be referred to as strain thy; one of its variants, a secondary mutant, isolate $\mathrm{VC}^{-} \mathrm{T}^{-}$, as strain thytlr (thymine low requirement). Strain thy, as noted previously, had about a 50-fold greater thymine requirement than did thytlr. Strain thy grew normally in the presence of thymidine (TdR), but this nucleoside inhibited the multiplaction of thytlr bacteria (Ivánovics, 1964). The mutants grown in the absence of pyrimidines at low termperature showed a normal replication of macromolecules and normal cell morphology. A shift up of the cultivation temperature to 
$37^{\circ}$ in the absence of thymine resulted in an unbalanced synthesis of macromolecules followed by the death of both thy and thytlr bacteria (Ivánovics, 1963, 1964). Our earlier study of the thymine auxotrophs was restricted to nutritional experiments. The purpose of the present work was to elucidate the site and nature of the block in the thymine pathway, and to gain some insight into thymine incorporation by tracer experiments and enzymic studies.

\section{METHODS}

Bacteria. The original mutants of Bacillus anthracis produced an extracellular proteolytic enzyme during growth. Since a contamination of cell extracts with proteolytic enzyme would affect the enzymic activity under investigation, non-proteolytic mutants of thy and thytlr were isolated. Bacteria of these strains were treated with ethylmethanesulphonate and the surviving organisms cultivated until marked sporulation occurred. Spores thus obtained were spread on milk agar plates and incubated. Colonies which developed without a proteolytic halo were purified by streaking. Stable non-proteolytic derivatives of strains thy and thytlr were used in all experiments. A prototrophic revertant obtained from thytlr, referred to as strain thytlrev, and a non-proteolytic wild-type strain NPA which came from the collection of Professor H. Smith (Birmingham) were also used in these studies. A non-capsulogenic derivative of NPA which will be referred to as strain $P$, was used throughout. Spores were prepared as described previously (Ivánovics, 1962), and a single batch of spores from each strain was used to provide inocula.

The strain Escherichia coli B was from the collection of this laboratory.

Media. A basal casein hydrolysate medium (BCM) was used for cultivating bacteria under defined conditions; it contained I $\mu \mathrm{g}$. thiamine $/ \mathrm{ml}$. and was prepared as previously described (Ivánovics, Varga \& Marjai, 1963). Milk agar plates were made from yeast-extract peptone agar by adding $40 \%(\mathrm{v} / \mathrm{v})$ centrifuged milk.

Chemicals. DL-L-tetrahydrofolic acid was prepared as recommended by Kisliuk (1957). All other chemicals used were reagent grade purchased from different commercial firms.

TPB buffer. 0.05 M-tris $+\mathrm{HCl}$ buffer $(\mathrm{pH} 7 \cdot 2)$ containing 0.1 mM-sodium phosphate.

Extinctions. The extinctions of the bacterial suspension was measured with a Spectromom 20, at $600 \mathrm{~m} \mu$. A spectrophotometer, MOM 20I (Budapest), served to measure extinction at different wavelengths.

Growth of organisms for enzyme assays. Bacteria of strains thy and thytlr were grown in BCM either in the absence of pyrimidine at $24^{\circ}$ or in the presence of thymidine and thymine, each at 5 to $10 \mu \mathrm{g} . / \mathrm{ml}$. at $37^{\circ}$. Except where otherwise stated, no pyrimidine was present in the medium when strains $\mathrm{P}$, thytlr rev or E. coli were grown.

To obtain a washed suspension, a culture in the exponential phase was centrifuged, the deposit washed with TPB, and suspended in TPB to give an extinction value of 0.7 ; this corresponded to $0.6 \mathrm{mg}$. dry bacteria $/ \mathrm{ml}$.

Crude bacterial extracts were made from $200 \mathrm{ml}$. cultures harvested in the middle log. phase as follows. The culture was rapidly cooled, centrifuged and the deposit washed with TPB. The packed bacteria were taken up in $5 \mathrm{ml}$. TPB and treated in a MSE Ultrasonic Power unit at $2^{\circ}$ to $4^{\circ}$ for $4 \mathrm{~min}$. The homogenate was sharply centrifuged, its supernatant fluid removed and $50 \mathrm{mg}$./streptomycin sulphate added to it; the bulky precipitate caused by the streptomycin was removed by centrifugation. 
Assay for thymidylate synthetase activity. A fraction, obtained from the crude bacterial extracts by precipitation with between $26 \%$ and $35 \%(\mathrm{w} / \mathrm{v})$ ammonium sulphate, as recommended by Wahba \& Friedkin (I962), was assayed for its activity by the Method III of these authors. The assay system was incubated at $25^{\circ}$ for $60 \mathrm{~min}$., and enzymic activity calculated from the values measured between 2 and $12 \mathrm{~min}$. One enzyme unit is defined as the amount of enzyme catalysing the formation of I $\mu$ mole thymidylate $/ \mathrm{hr} / \mathrm{mg}$. protein.

Thymidine:orthophosphate deoxyribosyl transferase. (Thymidine phosphorylase, E.C. 2.4.2.4.) Three tests were used to demonstrate this enzyme activity of bacteria. (I) The crude bacterial extract was mixed with an equal volume of $0.04 \mathrm{M}$-cysteine hydrochloride solution and $0 . \mathrm{I}$ M-potassium phosphate buffer $(\mathrm{pH} 7 \cdot 2)$ and the activity measured by the method of Razzel \& Khorana (1958). (2) A washed bacterial suspension containing $0.6 \mathrm{mg}$. dry bacteria/ml. was treated with toluene and assayed as recommended by Fangman \& Novick (1966). (3) Either strain P or thy was grown in BCM containing 0.1 to $\mathrm{I} \cdot 0 \mathrm{mM}$ of thymidine at $37^{\circ}$ overnight; a $\mathrm{I} / 20$ dilution was made from this inoculum with the same medium and incubated until the extinction reached to 0.7 to 0.8 . The supernatant fluid of the culture was sucked through a membrane filter (no. 4 Göttigen), the filtrate mixed with the same volume of $0.3 \mathrm{~N}-$ $\mathrm{NaOH}$, and its extinction measured at $300 \mathrm{~m} \mu$. The conversion of thymidine to thymine was calculated from the increase of extinction as recommended by Hotchkiss (I948).

Tests for enzymic degradation of uridine deoxyriboside (UdR) and adenine deoxyriboside $(A d R)$. To assay the enzyme capable of catalysing the phosphorolysis of UdR washed bacteria were made up in TPB with I mM-UdR. Assay systems were prepared in duplicate, with and without I mM sodium arsenate, both were incubated for $60 \mathrm{~min}$. at $37^{\circ}$. When I $\mu$ mole UdR is converted to uracil, there is an increase of $4^{\circ} \mathrm{I}$ in extinction value at $290 \mathrm{~m} \mu$ in the presence of $0 . \mathrm{I} \mathrm{N}-\mathrm{NaOH}$. This served to estimate the enzyme activity from the amount of uracil formed. When the enzyme activity was measured by the formation of sugar from the nucleoside, a sample from the assay system was deproteinized with $\mathrm{HClO}_{4}(0.5 \mathrm{M})$, and the clear supernatant fluid heated in boiling water for $3 \mathrm{~min}$. The amount of deoxyribose, both free and phosphorylated, was determined by the diphenylamine test (Burton, 1956). A sample was also taken from the assay system without arsenate, deproteinized by $\mathrm{Ba}(\mathrm{OH})_{2}+\mathrm{ZnSO}_{4}$ (Manson \& Lampen, 195I) to determine the free sugar.

The degradation of AdR could not be followed in a way similar to that for UdR. Therefore, a qualitative test was devised inolving thin-layer chromatography; this gave an indication of the decomposition of AdR by washed bacteria. The technique of chromatography was as described in the next paragraph.

Assay for nucleoside:purine (pyrimidine) deoxyribosyl-transferase (E.C. 2.4.2.6.). Different unlabelled deoxyribonucleosides were used as donors and tritiated thymine as acceptor for the deoxyribose moiety. The reagent to detect the enzyme activity contained $8 \mathrm{~m}$-mole of the deoxynucleoside and $3 \mathrm{~m}$-mole of tritiated thymine $(2 \mu \mathrm{c} / \mathrm{ml}$. activity) dissolved in TPB diluted I/ 10 with water. Two $\mathrm{ml}$. of the reagent was mixed with same volume of either washed bacterial suspension or the uncentrifuged ultrasonic fraction and incubated for $60 \mathrm{~min}$. at $37^{\circ}$. The assay system was rapidly cooled and centrifuged; $12 \mathrm{mg}$. charcoal were added to $3 \mathrm{ml}$. of the supernatant fluid, and shaken for $15 \mathrm{~min}$. The charcoal was sedimented, and eluted by a mixture of 8 vol. ethanol + I vol. water $+\mathrm{I}$ vol. ammonium hydroxide solution ( $0.88 \mathrm{sp}$.gr). 
Elution done 5 times with $5 \mathrm{ml}$. portions of the mixture. Recovery of the radioactivity in the pooled eluate amounted to $95 \%$. With the aid of an intensive cool air stream, the volume of the pooled eluate was evaporated to about $\mathrm{I} \mathrm{ml}$. The exact volume if the concentrate was measured by weight on an analytical balance. Samples (20 to $40 \mu \mathrm{l}$.) of eluate were put on a thin layer of cellulose ( $\mathrm{MN} 300$ ) containing $3 \%$ of $\mathrm{Al}(\mathrm{OH})_{3}$, and run with a solvent of $15 \mathrm{ml}$. $n$-butanol $+60 \mathrm{ml}$. acetone $+20 \mathrm{ml}$. water + $5 \mathrm{ml}$. concentrated ammonium hydroxide. A very good resolution of thymine and thymidine was achieved in this way. $R_{F}$ values: thymine $=0.55$; thymidine $=0.66$; $\mathrm{UdR}=0.43$; uracil $=0.32$.

Material scraped off the spots of thymine and thymidine was suspended in scintillation liquid and its activity counted. Scintillation liquid was $0.5 \mathrm{~g}$. POPOP and $5 \mathrm{~g}$. PPO in I 1. toluene. Radioactivity was counted in a TRI Carb Packard, Model 2IOI, scintillation spectrometer. The amount of radioactive thymine converted to thymidine was calculated from the percentage distribution of the label between the base and its nucleoside. Neglecting the loss of activity which occurred during isolation of products by charcoal treatment, enzyme activity was expressed by the amount of thymidine formed $\mu \mathrm{mole} / \mathrm{hr} / \mathrm{ml}$. bacterial suspension.

Determination of bacterial multiplication. Bacillus anthracis is a chain former, therefore the bacterial protein content of the culture was determined instead of colony count. A $0.5 \mathrm{ml}$. sample was mixed with $0.5 \mathrm{ml}$. cold $10 \%$ (w/v) TCA and centrifuged; the bacteria were washed twice with $5 \%$ TCA, finally suspended in $0.5 \mathrm{ml}$. of $10 \%$ $\mathrm{NaOH}$, and kept overnight in cold. The protein content of the extract was determined by the method of Lowry et al. (I95I). The number of generations was calculated by the formula $\left(\log A_{t}-\log A_{0}\right)$ divided by 0.30I. $A$ is the amount of protein per ml. at $o$ and $t$ times, respectively.

Incorporation of thymine into bacteria. Tritiated thymine $\left(-\mathrm{CH}_{\mathbf{3}^{-}}{ }^{3} \mathrm{H}\right)$ was obtained from the Hungarian State Isotopic Laboratory. The stock solution contained $\mathrm{I} \cdot 173 \mathrm{mg}$. thymine $/ \mathrm{ml}$. with an activity of $1 \cdot 077 \mathrm{mc} / \mathrm{ml}$. Labelled thymine was diluted with cold thymine as appropriate.

Tritiated thymine, $5 \mu \mathrm{g} . / \mathrm{ml}$. (I $\mu \mathrm{c} / \mathrm{ml}$. activity), was added to bacteria growing exponentially in BCM. Samples of the bacterial culture $(0.1 \mathrm{ml}$.) were taken at intervals and added to $5 \mathrm{ml}$. cold $5 \%$ TCA containing $10 \mu \mathrm{g}$. thymine $/ \mathrm{ml}$., sucked through a membrane filter, followed by several washings of the filter with $2 \mathrm{ml}$. cold TCA and cold saline. Radioactivity of the dried filter was measured; counts given by the zero time sample was considered background activity and subtracted from the timed sample.

\section{RESULTS}

\section{Heat-activated block in the de novo pathway of the chromosome replication}

Previous studies (Ivánovics, 1964) suggested the existence of a block in thymidylate5-phosphate synthesis which exerts its effect on the chromosome replication in the mutants only at an elevated temperature. Table $\mathrm{I}$ shows that no thymidylate synthetase activity was detected in preparations obtained from mutants grown at $37^{\circ}$ with exogenous pyrimidine. However, this enzyme activity was found in preparations from the mutants cultivated at $25^{\circ}$ and in the preparations obtained from prototrophic wild-type and revertant bacteria (strain thytlrev) grown at $37^{\circ}$. The same enzyme activity was recovered from Escherichia coli cultivated at $37^{\circ}$. 
Table 2 shows that there was no difference in the heat sensitivity of the enzymic activity of preparations obtained either from prototrophic or from thymine-dependent bacteria.

The lack of thymidylate synthetase activity in preparations of thytlr bacteria cultivated with exogenous thymine at $37^{\circ}$ was not due to the presence of an inhibitor of this enzyme since, if this were the case, the inactive preparation of thytlr would inhibit the enzyme activity of a preparation from the prototrophic bacteria. No such an effect was observed.

\section{Table I. Specific thymidylate synthetase activity of individual preparation} obtained from bacteria grown at low and elevated temperature

For growing strains thy and thyltr at $37^{\circ}$, casein hydrolysate medium BCM contained $5 \mu \mathrm{g}$./ml. thymidine and thymine, respectively. Zero value indicates that less than $0.0 \mathrm{r}$ enzyme unit was found in each of 2 to 4 individual preparations investigated

\begin{tabular}{lcc} 
& \multicolumn{2}{c}{$\begin{array}{c}\text { Specific enzyme activity: } \mu \text { mole/ } \\
\text { hr/mg. protein from bacteria } \\
\text { grown at }\end{array}$} \\
B. anthracis, P & $\overbrace{}^{25^{\circ}}$ & $37^{\circ}$ \\
B. anthracis, thy & N.I.* & 0.078 \\
& 0.065 & 0 \\
B. anthracis, thyltr & 0.078 &. \\
& 0.075 & 0 \\
B. anthracis, thyltrrev & 0.077 &. \\
E. coli B & $0.08 \mathrm{I}$ &. \\
& N.I. & 0.088 \\
& N.I. & 0.079 \\
& $*$ Not investigated. &
\end{tabular}

Table 2. Inactivation of thymidylate synthetase activity of preparations by heating at $50^{\circ}$ in tris buffer-Na phosphate at $\mathrm{pH} 7 \cdot 2$

$\begin{array}{ccc}\begin{array}{c}\text { Time of } \\ \text { heating } \\ \text { (min.) }\end{array} & \begin{array}{c}\text { Specific enzyme activity of } \\ \text { preparation from strain }\end{array} \\ 0 & 0.075 & P \\ 5 & 0.070 & 0.070 \\ 10 & 0.052 & 0.065 \\ 15 & 0.032 & 0.047 \\ 20 & 0.023 & 0.032 \\ 30 & 0.009 & 0.019 \\ & & 013\end{array}$

Incorporation of thymine by strains of Bacillus anthracis

A summary of results is shown in Table 3. Only an insignificant incorporation of label was detected in prototrophic bacteria at either temperature and in the mutants at $25^{\circ}$. On the other hand, a marked uptake of thymine by strains thytlr and thytlr rev was observed at $37^{\circ}$, although the revertant was a thymine-independent derivative of thytlr with thymidylate synthetase activity at $37^{\circ}$. A striking feature of the thymine 
incorporation was its dependence on temperature. Apparently the intactness of the pathway leading to thymidylate synthetase was not the only factor which regulated thymine uptake. Strain thy could not be examined under identical condition since this strain does not grow at such a low concentration of thymine.

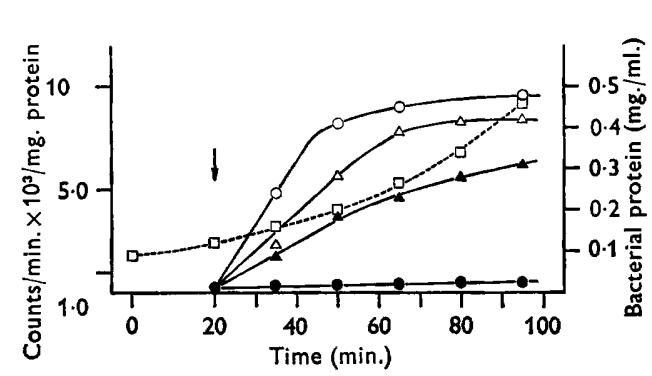

Fig. I

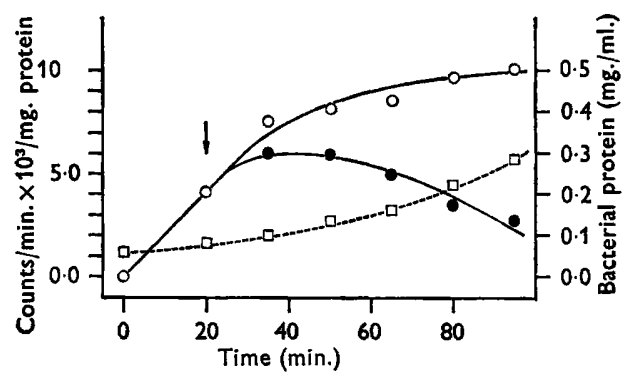

Fig. 2

Fig. I. The effect of different deoxyribonucleosides on the incorporation of tritiated thymine into prototrophic strain P of Bacillus anthracis. A culture growing exponentially in casein hydrolysate medium $\mathrm{BCM}$ containing $5 \mu \mathrm{g}$. labelled thymine $/ \mathrm{ml}$. with I $\mu \mathrm{C}$ activity $/ \mathrm{ml}$. was divided into four samples at $20 \mathrm{~min}$.; they were supplemented with different nucleosides; $20 \mu \mathrm{g} . / \mathrm{ml}$. each. O, Thymine only (T); O, T +AdR; $\triangle, T+U d R ; \Delta, T+C d R ; \square$, bacterial protein in culture $(\mathrm{mg} . / \mathrm{ml}$.). The growth rates of the bacteria were identical in all cases; the generation time was $45 \mathrm{~min}$.

Fig. 2. The incorporation of tritiated thymine into prototrophic Bacillus anthracis in the presence of $\mathrm{AdR}$ and TdR. $20 \mu \mathrm{g}$. AdR $/ \mathrm{ml}$. and $5 \mu \mathrm{g}$. tritiated thymine $/ \mathrm{ml}$. with I $\mu \mathrm{c}$ activity $/$ $\mathrm{ml}$. was added to an exponentially growing culture. The culture was divided in two parts at $20 \mathrm{~min}$.; one of them was reincubated while the other was supplemented with $5 \mu \mathrm{g}$. thymidine/ $\mathrm{ml}$. before reincubation. Incorporation of thymine in systems: $\mathrm{O}, \mathrm{T}+\mathrm{AdR} ; \mathbf{O}, \mathrm{T}+$ AdR + TdR; $\square$, weight of bacterial protein.

\section{Table 3. Thymine incorporation into Bacillus anthracis at $25^{\circ}$ and $37^{\circ}$}

Bacteria were grown overnight at $25^{\circ}$ in casein hydrolysate medium BCM containing unlabelled thymine $5 \mu \mathrm{g}$. $/ \mathrm{ml}$. The cultures were diluted $\mathrm{I} / \mathrm{IO}$ with the same medium and reincubated at $37^{\circ}$ until their extinction reached to 0.2 ; this was considered o time when tritiated thymine I $\mu \mathrm{c} / \mathrm{ml}$. was added to the cultures. Reincubation was either $25^{\circ}$ or $37^{\circ}$.

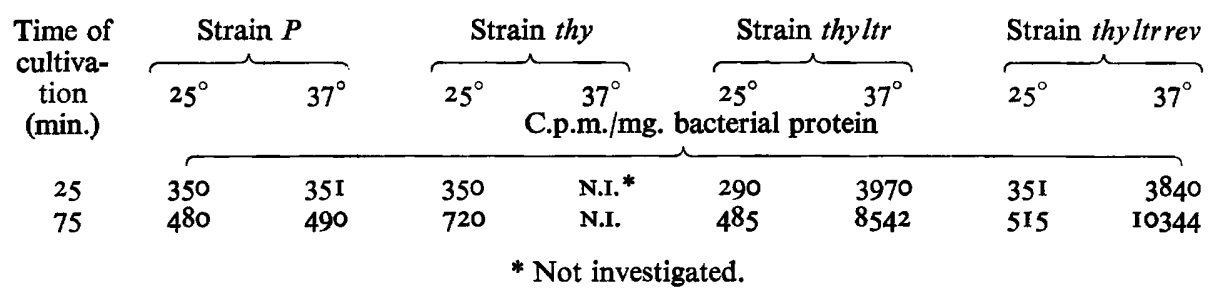

Exogenous thymine utilization by strains of Bacillus anthracis was increased in the presence of various deoxyribonucleosides. Figure I shows that prototrophic bacteria readily incorporated thymine in the presence of deoxyribonucleosides; AdR was most effective in this respect, $\mathrm{UdR}$ is next, whilst CdR exhibited only a moderate effect. By contrast, adenosine, deoxyribose and thymidine were unable to enhance the effect of label-incorporation into the acid-insoluble material of prototrophic bacteria. Moreover, thymidine inhibited thymine uptake into prototrophic bacteria even in the presence of AdR (Fig. 2). 
The addition of thymidine to the culture stopped thymine uptake by prototrophic bacteria, although this did not affect the growth rate of the bacteria. This particular effect of thymidine was also valid for thy and thytlr bacteria when they were grown at $37^{\circ}$. Multiplication of thy bacteria was not supported by a low concentration of thymine $(5 \mu \mathrm{g} . / \mathrm{ml}$.), therefore no label was taken up under this condition. Thymidine itself, on the other hand, gave a good growth of this organism. Deoxyribonucleosides (e.g. AdR) augmented the thymine uptake by thy bacteria, resulting in label incorporation and growth. Label incorporation, however, was blocked when thymidine was present in the culture (see Fig. 3).

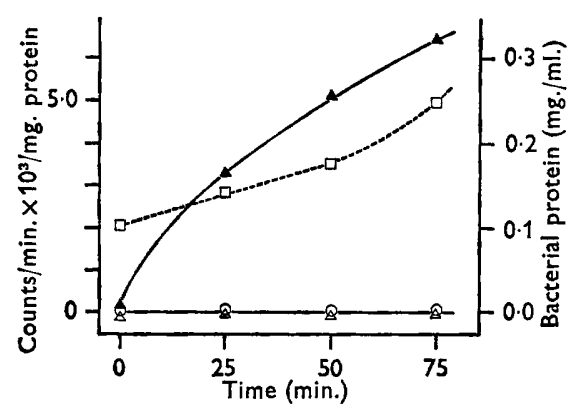

Fig. 3

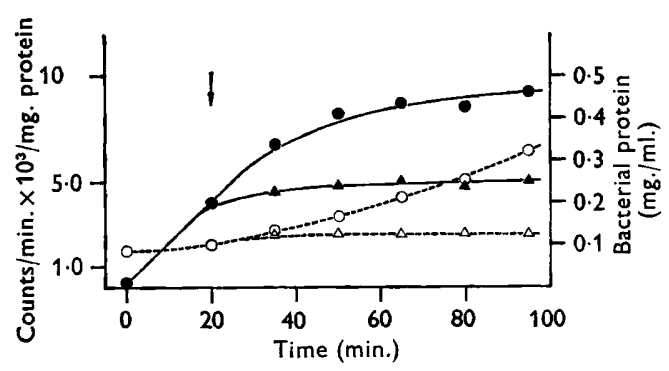

Fig. 4

Fig. 3. The effect of different deoxyribonucleosides on the incorporation of tritiated thymine into Bacillus anthracis thy. Bacteria were grown in casein hydrolysate medium BCM containing $5 \mu \mathrm{g}$. thymidine/ml. until an extinction value of 0.3 . The bacteria were centrifuged down, washed with BCM medium and suspended in $40 \mathrm{ml}$. BCM medium which contained $5 \mu \mathrm{g}$. thymine $/ \mathrm{ml}$. with I $\mu \mathrm{C}$ activity $/ \mathrm{ml}$. The suspension was distributed in Ioml. samples and the samples supplemented with nucleosides. The growths of individual cultures were identical. $\square$, Protein content of the cultures; generation time of bacteria, 60 min. Incorporation of thymine: $\Delta, 20 \mu \mathrm{g}$. AdR $/ \mathrm{ml}$. thymine; $0,5 \mu \mathrm{g}$. thymidine $/ \mathrm{ml}$. + thymine; $\Delta$, AdR + thymidine + thymine.

Fig. 4. The growth of strain thyltr of Bacillus anthracis and the incorporation of thymine in the presence and absence of thymidine. Bacteria were grown in casein hydrolysate medium BCM with $5 \mu \mathrm{g}$. unlabelled thymine $/ \mathrm{ml}$.; I $\mu \mathrm{C}$ tritiated thymine $/ \mathrm{ml}$. was added at $o$ time and the culture reincubated. The culture was divided into equal volumes; at $20 \mathrm{~min}$. thymidine $\mathrm{I} \mu \mathrm{g}$. $/ \mathrm{ml}$. was added to one of the samples; the other served as control. Incorporation of thymine: $\boldsymbol{\theta}$, in absence of thymidine; $\boldsymbol{\Delta}$, in presence of thymidine; $O$, bacterial protein without thymidine, and, $\Delta$, with thymidine.

The inhibitory effect of thymidine on thymine uptake by Bacillus anthracis was most notably exhibited by mutant thytlr; addition of thymidine to the culture growing with thymine at $37^{\circ}$ stopped both label-incorporation and growth (Fig. 4).

\section{Examination of enzymes involved in metabolism of pyrimidine nucleosides}

Deoxynucleoside phosphorylases. Phosphorolytic reactions are known to participate both in the degradation of nucleosides in the presence of orthophosphate yielding deoxyribose I-phosphate and base, and in the formation of deoxyribonucleoside from sugar-phosphate with any of the nucleic acid bases. As far as we are aware, nothing is known of these enzymic reactions in Bacillus anthracis; therefore it appeared rewarding to extend our study in this direction. Crude extracts from bacteria grown in the presence of Io to $20 \mu \mathrm{g}$. thymidine $/ \mathrm{ml}$. were assayed for thymidine phosphorylase 
activity. Material from mutant strain thytlr could, of course, only be obtained from bacteria cultivated without this nucleoside. Values were found to be very low in all cases; specific enzyme activities of preparations varied between 0.2 and 0.3 , whilst those from Escherichia coli, for comparison, showed a value of $5 \cdot 2$ to $5 \cdot 8$. When enzyme assays were made with washed bacterial suspensions, no thymidine phosphorylase activity was detected in the strains of $B$. anthracis. On the other hand, the $E$. coli. suspension was effective in degrading thymidine by phosphorolysis.

Growth of mutant thy was not sustained by a low concentration of thymine, although it grew well on thymidine concentrations as low as 2 to $5 \mu \mathrm{g} . / \mathrm{ml}$. Should this organism

\title{
Table 4. Degradation of thymidine into thymine by exponentially growing bacteria
}

\begin{abstract}
Flasks with casein hydrolysate medium BCM containing either $0 \cdot \mathrm{I}$ or $\mathrm{I} \cdot 0 \mu \mathrm{M}$ of thymidine were inoculated and incubated overnight; dilutions of cultures were made with same medium and reincubated at $37^{\circ}$ with shaking. The cultures were harvested at an extinction of 0.7 in Expt. I, and at 0.5 in Expt. 2; they were membrane-filtered and mixed with an equal volume of $0.2 \mathrm{~N}-\mathrm{NaOH}$. Their extinctions were measured at $300 \mathrm{~m} \mu$; a noninoculated medium served as a blank.
\end{abstract}

TdR concentration in medium $(\mu \mathrm{M})$

\begin{tabular}{|c|c|c|c|}
\hline \multicolumn{2}{|c|}{ Expt. I :0. I } & \multicolumn{2}{|c|}{ Expt. 2: I·O } \\
\hline $\begin{array}{l}\text { Change of } \\
\text { extinction* }\end{array}$ & $\begin{array}{l}\text { Thymine formed } \\
(\mu \mathrm{mole} / \mathrm{ml} .)\end{array}$ & $\begin{array}{l}\text { Change of } \\
\text { extinction }\end{array}$ & $\begin{array}{l}\text { Thymine formed } \\
(\mu \mathrm{mole} / \mathrm{ml} .)\end{array}$ \\
\hline+0.008 & 0.004 & +0.006 & 0.003 \\
\hline-0.040 & Zero value & -0.003 & Zero value \\
\hline+0.192 & 0.106 & +0.260 & $0 \cdot 144$ \\
\hline
\end{tabular}

* Multiplied by 2 when the amount of thymine was calculated. Minus values may derive from an exogenous product released by bacteria during growth.

have an effective thymidine phosphorylase activity, the bacteria would be expected soon to exhaust the low concentration of thymidine in the medium by splitting it to thymine which would not be utilizable. To test this, Bacillus anthracis and Escherichia coli were cultivated in the presence of thymidine and the conversion of thymidine to thymine determined. Thymidine phosphorylase is known to be an inducible enzyme in $E$. coli, therefore bacteria used as the inoculum were also grown in the presence of high concentrations of thymidine. Table 4 shows the results. Escherichia coli split thymidine considerably during its growth, whereas the strains of $B$. anthracis did not exhibit a significant degradation of it. The very low rate of thymidine degradation either with crude extracts of $B$. anthracis or with living bacteria did not furnish evidence for the existence of thymidine phosphorylase in this organism.

In contrast to these observations, a Imarked phosphorolysis of UdR was shown by Bacillus anthracis. As shown by Table 5, a resting bacterial suspension of prototrophic $B$. anthracis decomposed UdR, releasing free base but no sugar; however, both base and sugar accumulated in equimolar quantity in the assay system with arsenate. Mutant thytlr cleaved UdR by releasing both base and sugar in the absence of arsenate, which indicates that deoxyribose was not catabolysed by this mutant. An evidence for phosphorolytic cleavage of UdR was furnished by the identification of sugar-phosphate in the assay system of thytlr bacteria when a sample was taken from 
it, treated with $\mathrm{Zn}+\mathrm{Ba}$ reagent (Manson \& Lampen, 195I), and the sugar determined in the supernatant fluid. In Expt. I (see Table 5) only $0.04 \mu$ mole diphenylaminepositive substance $/ \mathrm{hr} / \mathrm{ml}$. was left in the supernatant fluid, the bulk of deoxyribose was removed by the $\mathrm{Zn}+\mathrm{Ba}$ treatment which indicated its phosphorylated form.

Table 5. Release of uracil and deoxyribose from UdR by resting bacterial suspensions of Bacillus anthracis

\begin{tabular}{|c|c|c|c|c|}
\hline \multirow{2}{*}{$\begin{array}{l}\text { B. anthracis } \\
\text { strain }\end{array}$} & \multirow{2}{*}{$\begin{array}{l}\text { Expt. } \\
\text { no. }\end{array}$} & \multirow{2}{*}{$\begin{array}{l}\text { Presence of } \\
\text { arsenate }\end{array}$} & \multicolumn{2}{|c|}{$\begin{array}{l}\text { Products in suspension } \\
(\mu \mathrm{mole} / \mathrm{hr} / \mathrm{ml} .)\end{array}$} \\
\hline & & & Free uracil & Deoxyribose \\
\hline \multirow[t]{3}{*}{ Prototrophic } & I & - & 0.28 & 0.02 \\
\hline & 2 & - & 0.29 & 0.02 \\
\hline & 2 & + & 0.28 & 0.28 \\
\hline \multirow[t]{2}{*}{ thyltr } & I & - & 0.31 & 0.28 \\
\hline & 2 & - & 0.25 & 0.21 \\
\hline
\end{tabular}

Table 6. Deoxyribosyl transfer by resting bacteria in the presence of various deoxyribonucleosides as donors

\begin{tabular}{|c|c|c|c|c|}
\hline \multicolumn{5}{|c|}{$\begin{array}{l}\text { Assay system contained tritiated thymine } 3 \mu \text { mole } / \mathrm{ml} \text {, various deoxyribor } \\
\text { donors, and the washed bacterial suspension. More than one experiment } \\
\text { each assay system; the results show the mean values. } \\
\text { Amount of radioactive thymidine formed } \\
\text { by washed bacterial suspension of: }\end{array}$} \\
\hline & & & thracis & \\
\hline & E. coli & $\mathbf{P}$ & thy & thyltr \\
\hline & \multicolumn{4}{|c|}{ Thymidine formed $(\mu \mathrm{mole} / \mathrm{hr} / \mathrm{ml}$.) } \\
\hline $\mathrm{UdR}$ & $\mathrm{I} \cdot 73$ & 1.09 & $I \cdot 23$ & $I \cdot 36$ \\
\hline TdR & 0.78 & 0.50 & $0.8 \mathrm{I}$ & 0.64 \\
\hline $\mathrm{CdR}$ & $1 \cdot 23$ & $I \cdot 05$ & $I \cdot 14$ & $I \cdot 4 I$ \\
\hline AdR & $<0.03$ & $<0.03$ & $<0.03$ & $<0.03$ \\
\hline GdR & $<0.03$ & $<0.03$ & $<0.03$ & $<0.03$ \\
\hline
\end{tabular}

The degradation of AdR by the prototrophic and mutant strains of Bacillus anthracis was also demonstrated. The presence of both adenine and hypoxanthine in the assay system indicated the cleavage of AdR and partial deamination of the base. No attempt was, however, made to show the presence of phosphate-sugar in the reaction mixture. The phosphorolysis of AdR by $B$. anthracis was therefore only presumable.

Nucleoside:purine (pyrimidine) deoxyribosyl transferase. In this enzymic reaction tritiated thymine served as an acceptor of the deoxyribose moiety which came from different purine or pyrimidine deoxyribonucleosides. The results are summarized in Table 6. In some experiments, bacterial suspensions were homogenized by ultrasonic treatment and used as an enzyme preparation in the presence of UdR as donor. None of the homogenates of the strains of $B$. anthracis was capable of catalysing the transfer reaction, in contrast to the test made with the Escherichia coli homogenate 
where tritiated thymidine was formed; however, it was somewhat less (I.47 $\mu$ mole/ $\mathrm{hr} / \mathrm{ml}$.) than that formed by intact bacteria. In summary, an enzyme activity catalysing the transfer of the deoxyribosyl radical from pyrimidine deoxyribosides by the whole organisms of $\boldsymbol{B}$. anthracis was found; however, neither AdR nor GdR were capable of taking part in this reaction.

\section{DISCUSSION}

With different species of Enterobacteriaceae, variable phenotypes of thymine mutants, depending on the quantitative requirements of thymine, have been described (Alikhanian et al. 1966; Brietman \& Bradford, 1967a; Roepke, 1967). It has been considered that thymine mutants with low base requirements are actually double mutants (Harrison, 1965; Stacey \& Simpson, 1965; Alikhanian et al. 1966; Breitman \& Bradford, 1967 b; Eisenstark, Eisenstark \& Cunningham, I968), just as it was concluded in the case of thymine-dependent mutants of Bacillus anthracis (Ivánovics, I964). It has been pointed out by Breitman \& Bradford (I967b) that the second mutation results in lack of deoxyribose aldolase activity which is associated with a low thymine requirement of the bacteria. The ability to incorporate thymine into DNA at a low exogenous concentration also may be caused by a mutation involving the loss of deoxyribomutase (Munch-Petersen, 1968; Barth, Beacham, Ahmad \& Pritchard, 1967). The consequence of the second mutation is an intracellular accumulation of deoxyribose-I-phosphate which increases the utilization of exogenous thymine (Kammen, 1967; Breitman \& Bradford, 1967b). It has been suggested that genes controlling the catabolism of deoxyribonucleosides constitute an operon (Barth et al. 1968). This operon controls the production of thymidine phosphorylase, purine nucleoside phosphorylase (E.C. 2.4.2. I), deoxyribomutase and deoxyriboaldolase (E.C. 4. I . 2.4) which are capable of catalysing either the biosynthesis or breakdown of deoxyribonucleosides. The operon conception concerning deoxyribose catabolism has been advanced and the deo designation for this operon was suggested to indicate the genes determining enzymes necessary for growth on deoxythymidine or deoxyuridine as sole carbon source (Lomax \& Greenberg, 1968). Any of the mutations leading to a low thymine requirement in strains lacking thymidylate synthetase are also associated with a phenotype characterized by a sensitivity of bacterial growth to thymidine or to other deoxyribonucleosides (Alikhanian et al. I966; Eisenstark et al. 1968). As shown by Barth et al. (1967), thymine mutants of Salmonella typhimurium highly sensitive to thymidine are lacking in deoxyriboaldolase, and the less sensitive mutants lack deoxyribomutase.

In the present work the first mutation in Bacillus anthracis affected the capacity of bacteria to produce thymidylate synthetase at $37^{\circ}$. Similarly, this enzyme was detected in the extracts of thytlr $B$. anthracis thytlr bacteria grown with exogenous thymine at $37^{\circ}$; however, effective enzyme activity was found in extracts obtained from these mutants when grown at $25^{\circ}$. Apparently the heat sensitivity of DNA replication in the mutants could not be accounted for either by an alteration in the structure of enzyme protein which renders the enzyme extremely heat labile, or by an inhibitor of the thymidylate synthetase activity. It seems that the synthesis of this enzyme itself is a heat-labile process. Heat-sensitive thymine mutants are not uncommon among bacteria. Alikhanian et al. (I966) found that half their thymine mutants isolated from Escherichia coli $\mathrm{K} \mathrm{I} 2$ mapping at the site of thy locus were temperature- 
sensitive. We would stress that the majority of thymine auxotrophs of $B$. anthracis isolated by using ethylmethanesulphonate as mutagen, needed thymidine only at temperatures higher than $32^{\circ}$ (Ivánovics et al. I963), like the strain thy used in this study.

With the exception of thymidine, all the deoxyribonucleosides tested enhanced the incorporation of tritiated thymine into acid-insoluble material of Bacillus anthracis. Moreover, thymidine totally blocked thymine utilization by prototrophic bacteria and thymine auxotrophs. The rate of bacterial multiplication, however, appeared to be independent of exogenous thymine uptake except when thymidine was added to cultures of mutant thytlr growing in the presence of thymine; in this case both thymine incorporation and growth were arrested.

A striking feature of the enzymic make-up of Bacillus anthracis is the lack of thymidine phosphorylase activity. On the other hand, definite evidence was found that UdR was decomposed by phosphorolysis by protrophic and by thytlr bacteria. The absence of deoxyribose from the assay system of prototrophic bacteria indicated that deoxyribose-I-phosphate formed by the phosphorolytic enzyme was metabolized. Mutant thytlr was found, in contrast, to be incapable of metabolizing the sugarphosphate formed by the phosphorolysis of $\mathrm{UdR}$, indicating that either deoxyribose mutase or aldolase is missing in this strain. Although no detailed studies were made to analyse the decomposition of AdR, preliminary observations pointed to a probable phosphorolysis by $B$. anthracis.

Cultivation experiments with mutant thy suggested the presence of trans- $N$ deoxyribosylase in Bacillus anthracis (Ivánovics, I964). Since no phosphorylitic breakdown of thymidine could be detected in B. anthracis, the conversion of thymine to thymidine in the presence of deoxyribonucleosides could only be related to a deoxyribosyl transfer reaction. Indeed, tritiated thymine was converted into thymidine by washed bacterial suspensions in presence of unlabelled pyrimidine deoxyribonucleosides, whereas purine deoxyribonucleosides did not function as substrates in a transfer reaction. The deoxyribosyl transfer reaction appears to be specific as it is known under certain experimental conditions (Roush \& Betz, I958) and assay systems (Zimmerman \& Seidenberg, 1964). Although evidence was secured for the existence of deoxyribosyl transfer reaction in $B$. anthracis, further studies are needed to identify the presence of nucleoside:purine pyrimidine deoxyribosyltransferase in the organism.

It is hard to give a satisfactory explanation of increased thymine uptake by Bacillus anthracis in the presence of UdR and AdR, although phosphorolytic breakdown of these deoxyribonucleosides was either proved or rendered presumable. Secondary mutation in $B$. anthracis resulting in a block in the catabolism of deoxyribose which in turn increased the availability of intracellular deoxyribose donors rendered the bacteria capable of utilizing low concentrations of exogenous thymine as is known for some Enterobacteriaceae. Nevertheless, there are several points which do not allow a similar conclusion which is valid for Enterobacteriaceae as to the incorporation of thymine. These contradictory facts are as follows. (I) The lack of thymidine phosphorylase in $B$. anthracis does not allow the conversion of the accumulated deoxyribose-I-phosphate plus thymine to thymidine. (2) Exogenous thymidine prevents thymine uptake by either prototrophic or mutant bacteria, although thymidine itself is a deoxyribose donor in transfer reaction in resting bacteria. (3) In spite of that AdR did not serve as a deoxyribosyl donor in transfer reaction in resting bacteria, AdR 
highly increased the thymine incorporation in growing bacteria. The facts listed above obscure the mechanism of thymine incorporation in $B$. anthracis, therefore further data are needed for its complete explanation.

The authors are indebted to Dr J. McGeachie (Royal Infirmary, Glasgow) for help in preparing the manuscript.

\section{REFERENCES}

Alikhantan, S. J., Iljena, T. S., Kaliaeva, E. S., Kameneva, S. V. \& Sukhodolec, V. V. (I966). A genetical study of thymineless mutants of E. coli. Genet. Res., Camb. 8, 83.

Barth, P. T., Beacham, I., Ahmad, S. I. \& Pritchard, R. H. (1967). Properties of mutants defective in the catabolism of deoxynucleosides. Proc. Biochem. Soc., 447th meeting, p. 12.

Barth, P. T., Beacham, I., Ahmad, S. I. \& Pritchard, R. H. (1968). The inducer of the deoxynucleoside phosphorylase and deoxyriboaldolase in Escherichia coli. Biochim. biophys. Acta I6I, 554 .

Brertman, T. R. \& BRADFORD, R. M. (1967a). The absence of deoxyriboaldolase activity in a thymineless mutant of Escherichia coli strain 15 ; a possible explanation for the low thymine requirement of some thymineless strain. Biochim. biophys. Acta 138, 220.

BreitMAN, T. R. \& BRADFORD, R. M. (1967b). Metabolism of thymineless mutants of Escherichia coli. I. Absence of thymidylate synthase activity and growth characteristics of two sequential thymineless mutants. J. Bact. 93, 845 .

BuRTON, K. (1956). A study of the conditions and mechanisms of the diphenylamine reaction for the colorimetric estimation of deoxyribonucleic acid. Biochem. J. 62, 315.

Demerec, M., Adelberg, E. A., Clark, A. J. \& Hartman, P. E. (1966). A proposal for a uniform nomenclature in bacterial genetics. Genetics, Princeton 54, 61 .

Eisenstark, A., EISENSTARK, R. \& CunNINGHAM, S. (1968). Genetic analysis of thymineless thy mutants in Salmonella typhimurium. Genetics, Princeton 58, 498.

Fangman, W. L. \& Novick, A. (1966). Mutant bacteria showing efficient utilization of thymidine. J. Bact. 9r, 2390.

HarRIson, A. P. (1965). Thymine incorporation and metabolism by various classes of thymineless bacteria. J. gen. Microbiol. 4I, $32 \mathrm{I}$.

HoтchKiss, R. D. (1948). The quantitative separation of purines, pyrimidines, and nucleosides by paper chromatography. J. biol. Chem. 175, 315.

IváNOvics, G. (1962). The pathogenicity of Bacillus anthracis lysogenic with mutants of phage W. J. gen. Microbiol. 28, 87.

IvANovics, G. (1963). Unbalanced growth induced by temperature shift in a mutant of Bacillus anthracis. Biochem. biophys. Res. Commun. II, 343.

IvÁNovics, G. (1964). Temperature sensitivity of mutants of Bacillus anthracis caused by a block in thymine-nucleotide synthesis. J. gen. Microbiol. 35, 299.

Ivánovics, G., VARGA, I. \& MarJaI, E. (1963). Auxotrophs of Bacillus anthracis. Acta microbiol. Hung. 10, 409.

KAMMEN, H. O. (1967). Thymine metabolism in Escherichia coli. I. Factors involved in utilization of exogenous thymine. Biochim. biophys. Acta 134, $30 \mathrm{I}$.

KIsLIUK, R. L. (1957). Studies on the mechanism of formaldehyde incorporation into serine. J. biol. Chem. 227, 805 .

LomAX, M. S. \& Greenberg, G. R. (1968). Characteristics of the deo operon: role in thymine utilization and sensitivity to deoxyribonucleosides. J. Bact. 96, 5 or.

LoWry, O. H., Rosebrovgh, N. J., FARR, A. L. \& RANDALL, R. L. (195I). Protein measurement with the Folin phenol reagent. J. biol. Chem. 193, 265.

Manson, L. A. \& LAMPEN, J. O. (I95I). The metabolism of deoxyribonucleoside in Escherichia coli. J. biol. Chem. 193, 539.

MUNCH-PetERSEN, A. (I968). Thymineless mutants of Escherichia coli with deficiencies in deoxyribomutase and deoxyriboaldolase. Biochim. biophys. Acta 16x, 279.

Razzel, W. E. \& Khorana, H. (I958). Purification and properties of pyrimidine deoxyriboside phosphorylase from Escherichia coli. Biochim. biophys. Acta 28, 562. 
RoEPKe, R. R. (1967). Relation between different thymineless mutants derived from Escherichia coli. J. Bact. $93,1188$.

Roush, A. H. \& BeTz, F. R. (1958). Purification and properties of trans-N-deoxyribosylase. J. biol. Chem. 233, 26I.

StaceY, K. A. \& Simpson, E. (1965). Improved method for isolation of thymine-requiring mutant of Escherichia coli. J. Bact. 90, 554.

WaHBA, A. J. \& FRIEDKIN, M. (1962). The enzymatic synthesis of thymidylate. I. Early steps in the purification of thymidylate synthetase of Escherichia coli. J. biol. Chem. 237, 3795.

Zimmerman, M. \& SeidenberG, J. (I964). Deoxyribosyl transfer. I. Thymidine phosphorylase and nucleoside deoxyribosyltransferase in normal and malignant tumors. J. biol. Chem. 239, 2618. 